\title{
Experimental Investigation on the Availability of Yeast Cell Wall as an Interfacial Tension Reducer for Enhanced Oil Recovery
}

Yuichi Sugai ${ }^{*}$, Junpei Mikumo, Keita Komatsu and Kyuro Sasaki

Earth Resources Engineering, Kyushu University, Fukuoka, Japan

\begin{abstract}
We studied on the availability of residue of squeezed beer yeast whose principal component is yeast cell wall for enhanced oil recovery as an interfacial tension reducer. The cell wall solution was hydrothermally treated in order to elute amphiphilic substances such as phospholipids, proteins, and fatty acids from the cell wall to the solution under different conditions such as concentration of the cell wall, temperature and time of the hydrothermal treatment, and salinity. The cell wall solution which was hydrothermally treated with crude oil was also applied to the measurement of interfacial tension between the solution and crude oil. The interfacial tension was reduced with decrease in salinity and increase in concentration of the cell wall and temperature of the hydrothermal treatment. The time of hydrothermal treatment didn't have much influence on the interfacial tension reduction. The capability of the cell wall solution which had been hydrothermally treated with crude oil to reduce the interfacial tension became larger than that of the cell wall solution which had been hydrothermally treated without crude oil. It was suggested that those interfacial tension reductions were brought by phospholipids and proteins eluted from the cell wall. Core flooding experiments were carried out by injecting the cell wall solution which had been hydrothermally treated with and without crude oil after the water flooding as the primary oil recovery. $2.0 \%$ and $1.2 \%$ of original oil in place was additionally recovered by injecting the cell wall solution which had been hydrothermally treated with and without crude oil respectively. These results support an advantage of process injecting the cell wall solution without hydrothermal treatment into high temperature oil reservoir. The injection of the cell wall solution can be a promising EOR which has both high cost performance and low environmental load.
\end{abstract}

Keywords: Enhanced oil recovery; Yeast cell wall; Interfacial tension; Crude oil; hydrothermal treatment; Amphiphilic substance; Phospholipids; Proteins; Core flooding; In situ method

\section{Introduction}

Surfactant injection is one of the most effective enhanced oil recovery (EOR) techniques. Chemical surfactants however pose a few problems such as their high cost and a large environmental load because of its low biodegradability [1]. We've studied on the Microbial EOR (MEOR) and searched for low-cost nutrient for the bacteria. An agricultural fertilizer which is shown in Figure 1 was examined as a candidate of the low-cost nutrient in our MEOR study. In our MEOR study, all the culture media have been sterilized under hightemperature $\left(121^{\circ} \mathrm{C}\right)$ and high-pressure $(0.2 \mathrm{MPa})$ conditions by using an autoclave before the incubation experiments (Figure 1). Crude oil has been sometimes added into culture media and also sterilized by autoclaving. A remarkable dispersion of crude oil was observed in the culture solution consisting of the fertilizer after the autoclave treatment as shown in Figure 1, indicating the reduction of interfacial tension (IFT) between the solution and crude oil.

The fertilizer consists of the residue of squeezed beer yeast which mainly comprises the cell wall of beer yeast. Its cost is therefore extremely inexpensive such as $1.0 \mathrm{USD} / \mathrm{kg}$ of retail price. In addition, this fertilizer is also environmentally friendly because it is derived from natural substances such as beer yeast. In general, yeast cell wall is constructed with various kinds of phospholipids [2], proteins [35], fatty acids [6-7], and so on. Because these substances includes amphiphilic substances which have both hydrophilic groups and hydrophobic groups and emulsification functions of those substances have been reported so far [8-13], the yeast cell wall which includes those substances can be expected to be effective for the IFT reduction.

With these circumstances, we evaluated the availability of this cell wall for EOR as an alternative of chemical surfactants. One of the

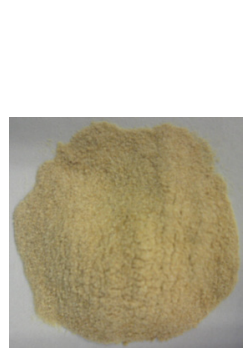

(a)

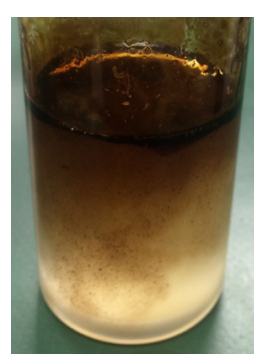

(b)

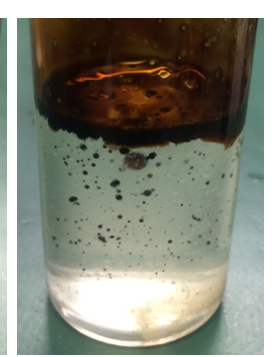

(c)
Figure 1: Photo images of the fertilizer mainly comprising the residue of squeezed beer yeast (a) and dispersion of crude oil in (b) the fertilizer solution and (c) deionized water.

advantages of utilizing the residue of squeezed beer yeast for EOR is the reduction of operation cost because it is a waste generated in beer brewing industries. The other advantage is the reduction of environmental load because it is a natural substance and can be expected to be decomposed by natural microorganisms. In addition, because the remarkable dispersion of crude oil was observed after the autoclave treatment of the mixture of the cell wall solution and crude

"Corresponding author: Yuichi Sugai, Kyushu University, Fukuoka, Japan, Tel: +81-92-802-3328; E-mail: sugai@mine.kyushu-u.ac.jp

Received May 19, 2017; Accepted June 15, 2017; Published June 22, 2017

Citation: Sugai Y, Mikumo J, Komatsu K, Sasaki K (2017) Experimental Investigation on the Availability of Yeast Cell Wall as an Interfacial Tension Reducer for Enhanced Oil Recovery. J Pet Environ Biotechnol 7: 329. doi: 10.4172/21577463.1000329

Copyright: @ 2017 Al Sugai Y, et al. This is an open-access article distributed under the terms of the Creative Commons Attribution License, which permits unrestricted use, distribution, and reproduction in any medium, provided the original author and source are credited. 
Citation: Sugai Y, Mikumo J, Komatsu K, Sasaki K (2017) Experimental Investigation on the Availability of Yeast Cell Wall as an Interfacial Tension Reducer for Enhanced Oil Recovery. J Pet Environ Biotechnol 7: 329. doi: 10.4172/2157-7463.1000329

Page 2 of 6

\begin{tabular}{|c|c|c|c|c|c|}
\hline Evaluation object & $\begin{array}{l}\text { Concentration of } \\
\text { the cell wall }\end{array}$ & $\begin{array}{l}\text { Hydrothermal treatment } \\
\text { temperature }\end{array}$ & $\begin{array}{l}\text { Hydrothermal } \\
\text { treatment time }\end{array}$ & Salinity & $\begin{array}{l}\text { Existence of crude oil } \\
\text { during the } \\
\text { hydrothermal treatment }\end{array}$ \\
\hline $\begin{array}{l}\text { Concentration of } \\
\text { the cell wall }(\mathrm{g} / \mathrm{L})\end{array}$ & $0,10,20,30,40,50$ & 50 & 50 & 50 & $0,10,20,30,40,50$ \\
\hline $\begin{array}{l}\text { Hydrothermal treatment } \\
\text { temperature }\left({ }^{\circ} \mathrm{C}\right)\end{array}$ & 120 & $\begin{array}{l}60,80,100,110,120 \\
130,140,160,180\end{array}$ & 120 & 120 & 120 \\
\hline $\begin{array}{l}\text { Hydrothermal } \\
\text { treatment time (min.) }\end{array}$ & 30 & 30 & $0,10,20,30,45,60$ & 30 & 30 \\
\hline Salinity $(\mathrm{g} / \mathrm{L})$ & 0 & 0 & 0 & $0,10,20,30,40$ & 0 \\
\hline $\begin{array}{l}\text { Existence of crude oil } \\
\text { during the } \\
\text { hydrothermal treatment }\end{array}$ & Nonexistence & Nonexistence & Nonexistence & Nonexistence & Existence \\
\hline
\end{tabular}

Table 1: Preparation conditions of the cell wall solution on each experiment.

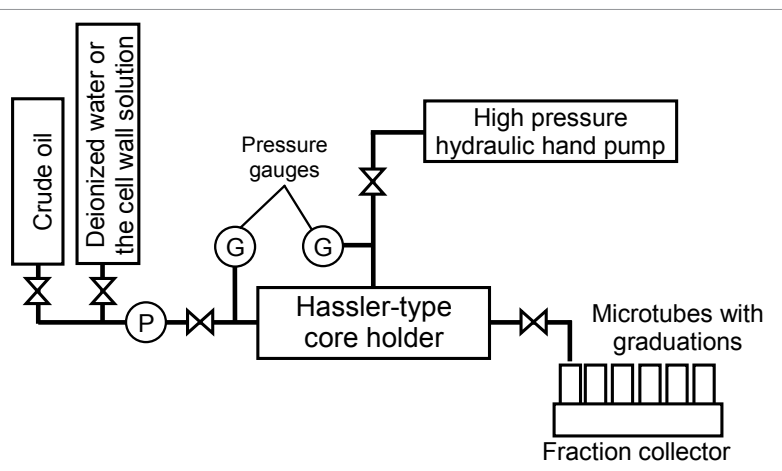

Figure 2: Schematic image of the core flooding system used in this study.

oil, this cell wall can be expected to be effective even at high temperature and applied to EOR in oil reservoir whose temperature is more than $100^{\circ} \mathrm{C}$ at which chemical surfactants may be deactivated.

In this study, the capability of the cell wall to reduce IFT between the cell wall solution and crude oil was quantitatively evaluated by the pendant drop method for measuring the IFT. The capability of the cell wall to bring EOR was also estimated through the core flooding experiments.

\section{Materials and Methods}

\section{Preparation of the cell wall solution}

The cell wall powder was put into pure water or saline water and sufficiently agitated under room temperature. The cell wall suspension was poured into a high pressure stainless bottle. The hydrothermal treatment of the cell wall suspension was performed using an autoclave or electric furnace. After cooling the suspension, supernatant or filtrate of the suspension was used for the experiments. Table 1 shows the preparation conditions of the cell wall solution. Various kinds of cell wall solution were prepared by changing the concentration of the cell wall powder, hydrothermal treatment temperature, hydrothermal treatment time, concentration of sodium chloride, and the existence of crude oil. The crude oil was added into the cell wall solution at $10 \%$ by the volumetric ratio before the hydrothermal treatment. After the hydrothermal treatment, the solution was separated from the crude oil by filtering the mixture with a filter paper whose pore size was $0.22 \mu \mathrm{m}$. The crude oil used in this study was light oil whose API gravity was approximately 40 . Viscosity of the crude oil was approximately $8.0 \mathrm{cP}$ at $25^{\circ} \mathrm{C}$.

\section{Measurement of IFT between the cell wall solution and crude oil}

IFT between the cell wall solution and crude oil was measured based on pendant drop method by using a contact angle meter (DMs-
401, Kyowa Interface Science Co., LTD., Tokyo). A pendant drop of crude oil was formed in the cell wall solution and the pendant drop was photographed. The analysis of the drop shape was based on the YoungLaplace equation [14-18] and the IFT was calculated.

\section{Measurement of concentration of phospholipids, proteins, and fatty acids in the cell wall solution}

Concentration of amphiphilic substances such as phospholipids, proteins, and fatty acids in the cell wall solution was measured in order to consider the mechanisms of the IFT reduction due to the cell wall.

Concentration of phospholipids in the cell wall solution was measured by using Wako phospholipids C assay (Wako Life Sciences, Inc., CA) which is an enzymatic method utilizing choline oxidase in a reaction which can be measured photometrically. The concentration of phospholipids was calculated by using a calibration curve formula which was derived from the relationship between the absorbance and concentration of choline chloride which is a constituent component of phospholipids.

Concentration of proteins in the cell wall solution was measured by using bicinchoninic acid kit for protein determination (Sigma-Aldrich Co. LLC., MO). The concentration of proteins was calculated by using a calibration curve formula which was derived from the relationship between the absorbance and concentration of albumin which is the most common protein.

Concentration of fatty acids in the cell wall solution was measured by using Wako non-esterified fatty acids (NEFA) assay (Wako Life Sciences, Inc., CA) which was an enzymatic method. The method for treating and measuring each substance was carried out in accordance with the instruction manual. The concentration of fatty acids was calculated by using a calibration curve formula which was derived from the relationship between the absorbance and concentration of oleic acid.

\section{Core flooding experiments}

The core flooding experiments were conducted by using a core flooding system which mainly consists of a hassle type core holder, pumps and reservoirs of fluids injected. Figure 2 shows the schematic image of the core flooding system which was used in this study (Figure 2). Berea sandstone core was installed into the core holder. Properties of the Berea sandstone cores which were used through the study are shown in Table 2. The length and diameter of the cores were approximately $72 \mathrm{~mm}$ and $45 \mathrm{~mm}$ respectively. The air permeability of the cores was approximately $50 \mathrm{mDarcy}$. The core was dried at $105^{\circ} \mathrm{C}$ for $10 \mathrm{~h}$. After the weight of dried core was measured, the core was soaked in deionized water and saturated with the water under decompression condition. After the weight of water-saturated core was 
measured, the core was installed into the core holder. The pore volume of the core was determined by the weight difference between dried core and water-saturated core. The pore volume and the porosity of the cores were approximately $19 \mathrm{ml}$ and $17 \%$ respectively. The experiments were carried out under atmospheric pressure and room temperature which was approximately $25^{\circ} \mathrm{C}$. The confining radial pressure which was $1.5 \mathrm{MPa}$ was applied to the core by water.

First, deionized-water was injected into the core with a flow rate of $0.1 \mathrm{~mL} / \mathrm{min}$ using high pressure pump in order to saturate the core with deionized-water completely. 5.0 pore volumes (PV) of crude oil were injected into the core with the same flow rate. Original oil in place (OOIP) equals the volume of water displaced by the oil

\begin{tabular}{|c|c|c|c|}
\hline Evaluation object & $\begin{array}{c}\text { EOR potential of } \\
\text { the cell wall } \\
\text { solution } \\
\text { hydrothermally } \\
\text { treated } \\
\text { without oil }\end{array}$ & $\begin{array}{c}\text { EOR potential of } \\
\text { the cell wall } \\
\text { solution } \\
\text { hydrothermally } \\
\text { treated } \\
\text { with oil }\end{array}$ & $\begin{array}{c}\text { Negative } \\
\text { control }\end{array}$ \\
\hline Diameter of the core (mm) & 44.6 & 44.7 & 44.5 \\
\hline Length of the core (mm) & 71.8 & 71.8 & 71.8 \\
\hline $\begin{array}{c}\text { Absolute air permeability } \\
\text { (mdarcy) }\end{array}$ & 51.2 & 47.3 & 49.8 \\
\hline Pore volume (mL) & 19.4 & 17.7 & 18.1 \\
\hline Porosity (\%) & 17.3 & 15.7 & 16.2 \\
\hline Initial oil saturation (\%) & 61.8 & 56.4 & 59.1 \\
\hline $\begin{array}{c}\text { Pore volume of pure water } \\
\text { injected (PV) }\end{array}$ & 2.2 & 1.8 & 4.6 \\
\hline $\begin{array}{c}\text { Pore volume of } \\
\text { the cell wall solution } \\
\text { injected (PV) }\end{array}$ & 2.7 & 2.5 & 0.0 \\
\hline
\end{tabular}

Table 2: Preparation conditions of the cell wall solution on each experiment.

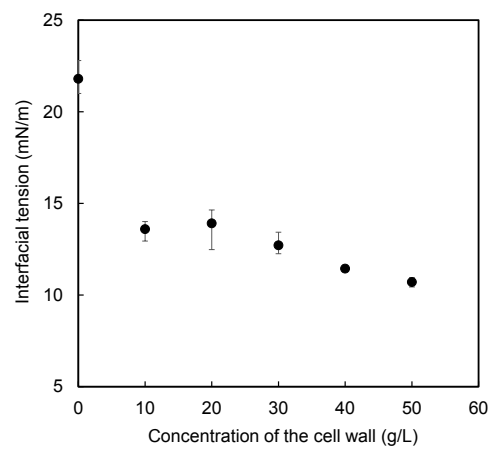

Figure 3: IFT between the crude oil and the cell wall solution which was prepared with different concentration of the cell wall.

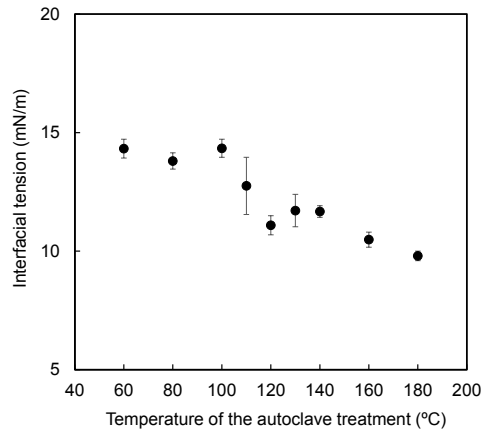

Figure 4: IFT between the crude oil and the cell wall solution which was prepared with different hydrothermal treatment temperature. flooding. After 2 weeks of aging, primary oil recovery was conducted by injecting deionized-water into the core with the same flow rate. The primary oil recovery was conducted until no more oil had been observed in the effluent. Effluent fluid was collected every $10 \mathrm{~min}$ into micro tubes with graduations for measuring and the amount of effluent oil and water was determined volumetrically. Subsequently, 3.0 PV of cell wall solution was injected into the core with the same flow rate. The cell wall solution injected was prepared as follows. The cell wall powder was put into deionized-water with the concentration of $50 \mathrm{~g} / \mathrm{L}$ and sufficiently agitated. The hydrothermal treatment of the cell wall suspension was performed at $120^{\circ} \mathrm{C}$ at $0.2 \mathrm{MPa}$ for $30 \mathrm{~min}$. Another cell wall suspension which was treated with crude oil at the same conditions was also prepared. The volume ratio between the oil and the suspension was $1 / 10$. After cooling the solution, the supernatant was filtered using membrane filters having a pore size of $0.2 \mu \mathrm{m}$ and the filtrate were recovered as the cell wall solution. The other core flooding experiment injecting deionized-water without cell wall after the primary oil recovery was also performed in parallel.

\section{Results and Discussion}

\section{IFT reduction between the crude oil and the cell wall solution}

Figure 3 shows the variation of IFT between the crude oil and the cell wall solution which was prepared with different concentration of the cell wall. All the solution used in this IFT measurement contained sodium chloride with the concentration of $10 \mathrm{~g} / \mathrm{L}$ and were treated at $120^{\circ} \mathrm{C}$ for $30 \mathrm{~min}$ without crude oil. IFT between the crude oil and the cell wall solution was between $10.7 \mathrm{mN} / \mathrm{m}$ and $13.9 \mathrm{mN} / \mathrm{m}$ while that between the crude oil and the saline water which was hydrothermally treated at the same conditions was $21.8 \mathrm{mN} / \mathrm{m}$. The IFT became lower as the concentration of the cell wall became higher. These results indicate that the elution amount of amphiphilic substances increased as the concentration of the cell wall was increased. The minimum IFT was observed with the solution which was prepared with $50 \mathrm{~g} / \mathrm{L}$ of the cell wall. These results indicate that the cell wall has a potential to reduce IFT between the crude oil and its solution.

Figure 4 shows the variation of IFT between the crude oil and the cell wall solution which was hydrothermally treated under different temperature. All the solution used in this IFT measurement were prepared with $50 \mathrm{~g} / \mathrm{L}$ of the cell wall, contained sodium chloride with the concentration of $10 \mathrm{~g} / \mathrm{L}$ and were treated for $30 \mathrm{~min}$ without crude oil. IFT reduction was not clearly observed when the cell wall solution which was hydrothermally treated below $100^{\circ} \mathrm{C}$ was used for the IFT measurement. On the other hand, the IFT was gradually decreased as the treatment temperature was increased. These results indicate that the elution amount of amphiphilic substances increased as the treatment temperature was increased. Temperature of the hydrothermal treatment should be preferably $120^{\circ} \mathrm{C}$ or above for the IFT reduction. The minimum IFT was $9.8 \mathrm{mN} / \mathrm{m}$ which was observed with the cell wall solution which had been hydrothermally treated less than $180^{\circ} \mathrm{C}$.

Figure 5 shows the variation of IFT between the crude oil and the cell wall solution which was prepared with different hydrothermal treatment time. All the solution used in this IFT measurement were prepared with $50 \mathrm{~g} / \mathrm{L}$ of the cell wall, contained sodium chloride with the concentration of $10 \mathrm{~g} / \mathrm{L}$ and were treated at $120^{\circ} \mathrm{C}$ without crude oil. Similar IFT was observed on all the solution which had been hydrothermally treated for 10 to $60 \mathrm{~min}$, therefore, the IFT reduction can be enough obtained by 10 -min treatment. This result also indicates that the IFT reduction can be maintained even if the solution is exposed to a high temperature for a long period of time. 
Figure 6 shows the variation of IFT between the crude oil and the cell wall solution containing sodium chloride with different concentration. All the solution used in this IFT measurement contained the cell wall with the concentration of $50 \mathrm{~g} / \mathrm{L}$ and were hydrothermally treated at $120^{\circ} \mathrm{C}$ for $30 \mathrm{~min}$. IFT became higher as the concentration of sodium chloride became higher, especially it increased obviously at $40 \mathrm{~g} / \mathrm{L}$ of sodium chloride. The capability of the cell wall to reduce IFT between its solution and oil is expected to be affected by sodium chloride like most chemical surfactants. Concentration of sodium chloride should be preferably less than $30 \mathrm{~g} / \mathrm{L}$ for the IFT reduction.

Figure 7 shows the variation of IFT between the crude oil and the cell wall solution which was prepared with different concentration of the cell wall and hydrothermally treated with the crude oil. The variation of IFT between the crude oil and the cell wall solution which was hydrothermally treated without crude oil was also shown in the same figure. All the solution used in this IFT measurement was hydrothermally treated at $120^{\circ} \mathrm{C}$ for $30 \mathrm{~min}$. When the concentration of the cell wall was $10 \mathrm{~g} / \mathrm{L}$ or more, IFT between the crude oil and the cell wall solution which was hydrothermally treated with crude oil became lower than that between the crude oil and the solution which was hydrothermally treated without crude oil. When the concentration of the cell wall was more than $30 \mathrm{~g} / \mathrm{L}$, the IFT was decreased less than $8.6 \mathrm{mN} / \mathrm{m}$ which was the lowest IFT in this study.

Amphiphilic substances may be more eluted from the cell wall to the solution and/or crude oil by hydrothermal treatment with crude oil. This result indicates that the IFT can be decreased by hydrothermal treatment of the solution with crude oil. In other words, the IFT can be in situ decreased by injecting the cell wall solution into oil reservoir having sufficiently high temperature such as $120^{\circ} \mathrm{C}$ or more.

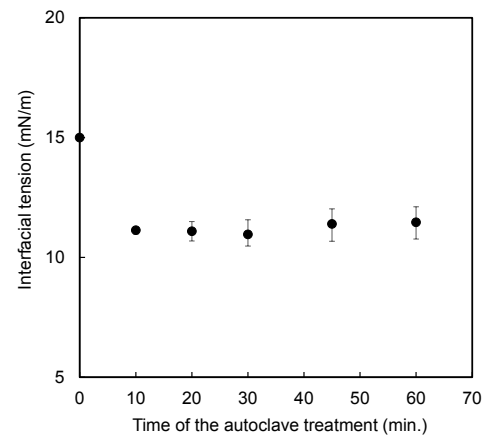

Figure 5: IFT between the crude oil and the cell wall solution which was prepared with different hydrothermal treatment time.

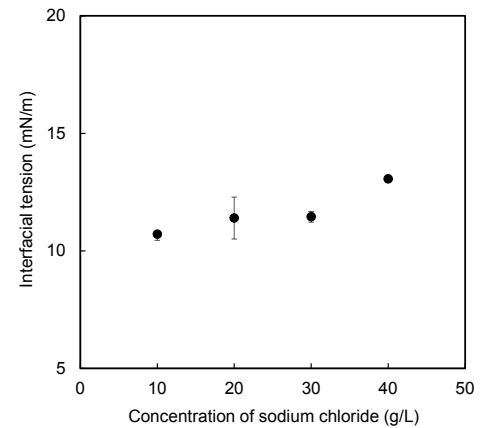

Figure 6: IFT between the crude oil and the cell wall solution containing sodium chloride with different concentration.

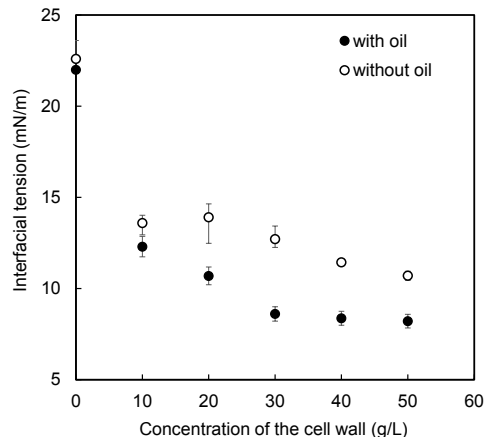

Figure 7: IFT between the crude oil and the cell wall solution which was prepared with different concentration of the cell wall and hydrothermally treated with the crude oil.

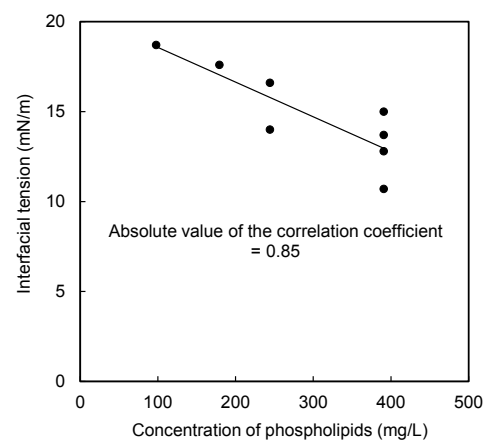

Figure 8: Relationship between the IFT and the concentration of phospholipids in the cell wall solution.

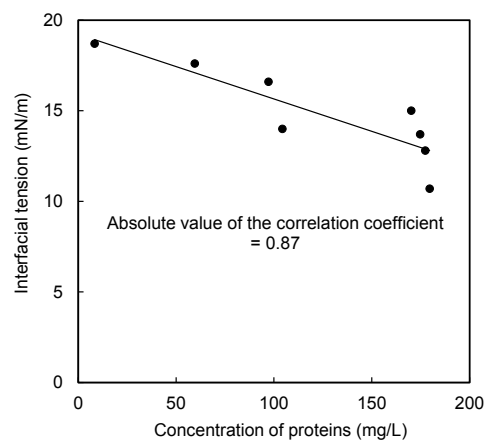

Figure 9: Relationship between the IFT and the concentration of proteins in the cell wall solution.

\section{Relationship between the IFT reduction and the concentration of phospholipids, proteins, and fatty acids in the cell wall solution}

Figure 8 shows the relationship between the IFT and the concentration of phospholipids in the cell wall solution. The decreasing trend can be observed with the increase of the phospholipids concentration. A linear regression of the IFT and the phospholipids concentration yields an absolute value of the correlation coefficient of 0.86 . Because the correlation coefficient between 0.8 and 1.0 indicates very strong correlation in accordance with the guide which was suggested by Evans [19], the relationship between the IFT and the concentration of phospholipids can be evaluated to be very strong.

Figure 9 shows the relationship between the IFT and the concentration of proteins in the cell wall solution. The decreasing trend can be also observed with the increase of the proteins concentration. 
A linear regression of the IFT and the proteins concentration yields a correlation coefficient of 0.87 . The relationship between the IFT and the concentration of proteins can be also evaluated to be very strong in accordance with the guide suggested by Evans [19].

Figure 10 shows the relationship between the IFT and the concentration of fatty acids in the cell wall solution. Although the decreasing trend can be observed with the increase of the fatty acids concentration, no clear relation is indicated between them when the IFT becomes lower than $15 \mathrm{mN} / \mathrm{m}$. A linear regression of the IFT and the fatty acids concentration therefore yields a lower correlation coefficient such as 0.57 . Because the correlation coefficient between 0.4 and 0.59 indicates moderate correlation in accordance with the guide which was suggested by Evans [19], the relationship between the IFT and the concentration of fatty acids can be evaluated to be moderate. Therefore, the fatty acids which were eluted from the cell wall may not have much influence on the IFT reduction.

\section{Effect of the cell wall on the enhancement of oil recovery}

Cumulative oil recovery which had been obtained in each core flooding experiment is shown in Figure 11. Although there was a little difference between three experiments, just less than $40 \%$ of OOIP was totally recovered by the injection of water and/or the cell wall solution.

In the early stage of the injection of the cell wall solution which had been hydrothermally treated without oil, a negligible amount of oil was drained from the core. Drainage of the remaining oil was started to be detected obviously after 0.7 to $0.8 \mathrm{PV}$ of injection of the cell wall solution while non-drainage of the remaining oil was detected

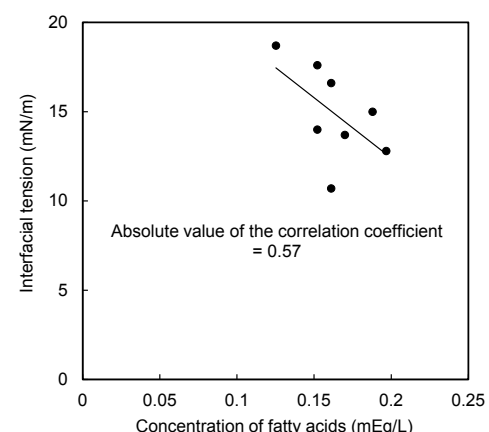

Figure 10: Relationship between the IFT and the concentration of fatty acids in the cell wall solution.

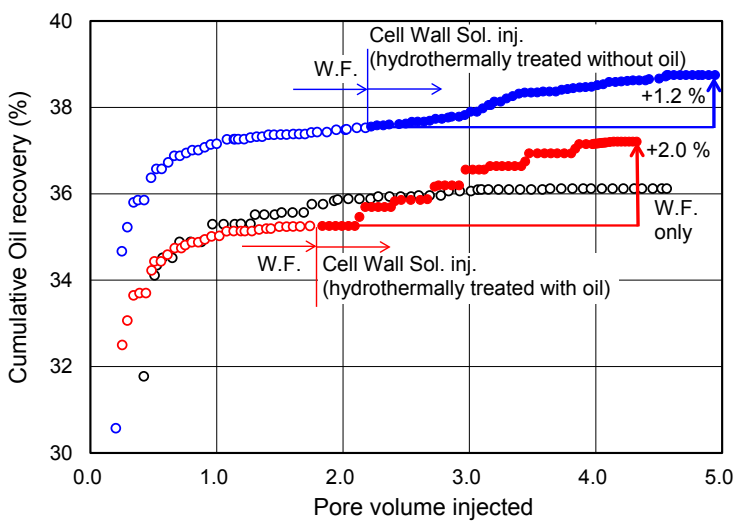

Figure 11: Cumulative oil recovery which had been obtained in each core flooding experiment. on the experiment injecting only water as shown by black open circles. Drainage of the remaining oil on the injection of the cell wall solution was observed until 1.3 PV of injection of the cell wall solution. As a result, $1.2 \%$ of OOIP had been recovered from the core by the injection of the cell wall solution.

On the other hand, drainage of the remaining oil was found more early by injecting the cell wall solution which had been hydrothermally treated with oil. Drainage of the remaining oil was observed after 0.3 PV of injection of the cell wall solution. As a result, $2.0 \%$ of OOIP had been recovered from the core by the injection of $2.6 \mathrm{PV}$ of the cell wall solution. The cell wall solution which was hydrothermally treated with oil is therefore more effective for enhancing oil recovery.

These results support an advantage of in situ process injecting the cell wall solution without hydrothermal treatment into reservoir whose temperature is more than $120^{\circ} \mathrm{C}$. That is, amphiphilic substances can be eluted to the solution from the cell wall and the IFT can be reduced in reservoir. Consequently, enhancement of oil recovery can be obtained. This in situ process has a few advantages that both surface facilities and operation costs for hydrothermal treatment of the cell wall solution can be unnecessary, and higher enhancement of oil recovery can be expected.

\section{Conclusions}

In this study, we estimated the availability of the residue of squeezed beer yeast which was comprised of the yeast cell wall for enhanced oil recovery. We evaluated the capability of the cell wall which was treated under several conditions to reduce interfacial tension (IFT) between its solution and crude oil. In addition, EOR potential of the cell wall solution was also evaluated through the core flooding experiments. The following conclusions were obtained through this study.

1) The cell wall solution which was hydrothermally treated has a capability to reduce IFT between its solution and crude oil.

2) IFT between the cell wall solution and crude oil became lower as the concentration of the cell wall became higher.

3) Temperature of the hydrothermal treatment of the cell wall solution is preferably $120^{\circ} \mathrm{C}$ or above for IFT reduction. Amphiphilic substances may be more eluted from the cell wall at $120^{\circ} \mathrm{C}$ or above.

4) IFT reduction can be enough obtained by 10-min hydrothermal treatmemt. In addition, the IFT reduction can be maintained even if the solution is exposed to a high temperature for a long period of time.

5) IFT between its solution including sodium chloride and crude oil became higher by as the sodium chloride concentration became higher. Concentration of sodium chloride should be preferably less than $30 \mathrm{~g} / \mathrm{L}$ for the IFT reduction.

6) The capability of the cell wall solution which had been hydrothermally treated with crude oil to reduce the IFT became extremely larger than that of the cell wall solution which had been hydrothermally treated without crude oil. The minimum IFT of this study, which was $8.2 \mathrm{mN} / \mathrm{m}$, was observed with the cell wall solution which was hydrothermally treated with crude oil at $120^{\circ} \mathrm{C}$ for $30 \mathrm{~min}$. Consequently, the IFT can be in situ reduced by injecting the cell wall solution without hydrothermal treatment into oil reservoir whose temperature is higher than $120^{\circ} \mathrm{C}$.

7) It is assumed that the IFT was reduced by amphiphilic substances such as phospholipids and proteins which were eluted from the cell wall.

8) EOR was clearly obtained by injecting the cell wall solution 
Citation: Sugai Y, Mikumo J, Komatsu K, Sasaki K (2017) Experimental Investigation on the Availability of Yeast Cell Wall as an Interfacial Tension Reducer for Enhanced Oil Recovery. J Pet Environ Biotechnol 7: 329. doi: 10.4172/2157-7463.1000329

Page 6 of 6

in the core flooding experiments. Additional oil recovery which was brought by the injection of the solution hydrothermally treated with and without crude oil was $2.0 \%$ and $1.2 \%$ of original oil in place respectively. In situ process that the cell wall solution is injected into reservoir without hydrothermal treatment may be economically and effectively advantageous method.

\section{Acknowledgement}

This work was supported by JSPS KAKENHI Grant Number 16K14524.

\section{References}

1. Ela MAE, Sayyouh H, Tayeb ESE (2014) An integrated approach for the application of the enhanced oil recovery projects. J Pet Sci Eng 3: 176-188.

2. James BMR, Angelo S, Denis KK (1975) Lipids of yeasts. Bacteriol Rev 39: 197-231.

3. Klis FM, Jong MD, Brul S, De Groot PW (2007) Extraction of cell surfaceassociated proteins from living yeast cells. Yeast 24: 253-258.

4. Eulogio V, Enrique H, FI Javier P, Rafael S (1984) Solubilization and analysis of mannoprotein molecules from the cell wall of Saccharomyces cerevisiae. J Gen Microbiol 130: 1419-1428.

5. Klis FM, Boorsma A, De Groot PW (2006) Cell wall construction in Saccharomyces cerevisiae. Yeast 23: 185-202.

6. Imamura Y, Hara S, Otsuka K (1980) Fatty acids as hydrophobic substance on cell surface of film strain of Saccharomyces. Agri Biol Chem 44: 1223-1229.

7. Mcelhaney RN (1976) The biological significance of alterations in the fatty acid composition of microbial membrane lipids in response to changes in environmental temperature. in Extreme Environments: Mechanisms of Microbial Adaptation, Academic Press, New York.

8. Hildebrandt E, Vrânceanu M, Nirschl H, Leneweit G (2013) Phospholipids as emulsifiers for micro/nano droplets suitable for biotechnological systems integration. La Houille Blanche 2: 68-73.

9. Yamano Y, Seike N (1983) Stability of emulsion prepared with soybean phospholipids and transfer of phospholipid to separated phases. Nippon Shokuhin Kogyo Gakkaishi 30: 618-623.

10. Rydhag L, Wilton I (1981) The function of phospholipids of soybean lecithin in emulsions. IJ Am Oil Chem Soc 58: 830-837.

11. Shah DO (1970) Surface chemistry of lipids. Adv Lipid Res 8: 347-431.

12. Beverung CJ, Radke CJ, Blanch HW (1999) Protein adsorption at the oil/water interface: Characterization of adsorption kinetics by dynamic interfacial tension measurements. Biophys Chem 81: 59-80.

13. Kanamoto R, Ohtsu M, Kito M (1977) Diversity of the soybean proteinphosphatidylcholine complex. Agri Biol Chem 41: 2021-2026.

14. Young $T$ (1805) An essay on the cohesion of fluids. Philosophical Transactions of the Royal Society 95: 65-87.

15. Laplace PS (1807) Theory of capillary attraction. Supplements to the 10 th book of Celestial Mechanics.

16. Pujado PR, Huh C, Scriven LE (1972) On the attribution of an equation of capillarity to young and Laplace, J Colloid Interface Sci 38: 662-663.

17. Pasandideh-Fard M, Chen P, Mostaghimi J, Neumanntic AW (1996) The generalized Laplace equation of capillarity I. Thermodynamic and hydrostatic considerations of the fundamental equation for interfaces. Adv Colloid Interface Sci 63: 151-178.

18. Chen P, Susnar SS, Pasandideh-Fard M, Mostaghimi J, Neumann AW (1996) The generalized Laplace equation of capillarity II. Hydrostatic and thermodynamic derivations of the Laplace equation for high curvatures. Adv Colloid Interface Sci 63: 179-193.

19. Evans JD (1996) Straightforward statistics for the behavioral sciences. BrooksCole Publishing Company, Pacific Grove, CA. 